\title{
Problems and prospects of waste processing and recycling of production containing rare earth metals
}

T. I. Yushina, Associate Professor, Head of the Department of Minerals Processing and Technogenic Raw Materials ${ }^{1}$, e-mail: yuti62@mail.ru

I. M. Petrov, CEO ${ }^{2}$

S. A. Chernyi, Associate Professor, Head of the Department of Technology and Integrated Mechanization ${ }^{3}$

A. I. Petrova, Post-Graduate Student ${ }^{4}$

${ }^{1}$ NUST MISiS College of Mining, Moscow, Russia.

2 INFOMINE Research Group LLC, Moscow, Russia.

${ }_{3}^{3}$ Berezniki Branch of the Perm National Research Polytechnic University, Berezniki, Russia.

${ }^{4}$ Research Institute of Comprehensive Exploitation of Mineral Resources of RAS (IPKON), Moscow, Russia.

\begin{abstract}
The demand for rare-earth metals (REMs), which are quite expensive and scarce resources, is constantly growing and there is a shortage of supply for individual metals. All this makes the task of the search for new sources of REMs, including man-caused ones, very important.

In solving these problems, a very promising direction is the development of REM recycling schemes, both directly from the wastes of the production of rare metals and other industries, and from the goods that have served their time, or in other words, the so-called end-of-life (EOL) goods. This direction of recycling seems to be the most efficient, reasoning from the volumes of REMs that pass to wastes in EOL goods, among which REM recycling from NdFeB magnets of electronic devices, fluorescent lamps, nickel-metal hydride $(\mathrm{NiMH})$ batteries, and a number of other RE-containing products has become predominant. For example, the degree of REM recovery in the recycling of magnets is $80-95 \%$; such a volume of secondary resources of rare earths is of serious commercial interest. As experts are assessing, the level of recycling of rare earths from fluorescent lamps will be $\sim 95 \%$, and it will be possible to recycle the lamps for another 30 years. When processing nickel-metal hydride (NiMH) batteries, up to $80 \%$ of REMs contained in them is returned to the commercial circulation.

Another important direction of obtaining REMs is the disposal of industrial wastes. Such technologies can be developed in the countries where REM products with high value added are not manufactured, however, there are mineral resources and advanced industry. For example, in Russia, such technologies are used at the Solikamsk Magnesium Works, which produces rare-metal production from loparite concentrate. At the Russian Rare Metals plant, there has been developed a technology for processing grinding wastes from the production of permanent magnets based on rare-earth metals, from which the high-purity compounds of neodymium, praseodymium, and dysprosium can be obtained.

Another technogenic resource for the development of REM recycling technologies in Russia are considerable, over 250 million tons, phosphogypsum wastes from the processing of Khibiny apatite concentrate. The Skaygrad Group has developed a technology that allows to obtain from 500 to 2000 tons of a sum of 17 rare-earth metals per year, with a total mass quota up to $99.5 \%$ of REMs.

In general, it can be concluded that the technologies of REM recycling from both end-of-life goods and products, and industrial wastes will continue to develop not only in the countries of the Asia-Pacific region or EU, but also in Russia in spite of relatively low content of rare earths in them.
\end{abstract}

Key words: rare-earth metals, recycling, waste processing, electronic devices, NdFeB magnets, NiMH batteries, grinding wastes, phosphogypsum, REM oxides, end-of-life goods

DOI: $10.17580 / \mathrm{nfm} .2021 .01 .03$

\section{Introduction}

A number of factors dictate the urgency of studying the possibilities of recycling rare earth metals (REMs). For example, rare earths serve as a material and technical basis for many advanced technologies in various sectors of the economy. Their unique properties are critical for achieving high strength, thermal, energy and optical parameters of innovative products. An effective equivalent alternative for REMs has not been found today [1-2].

REMs are still quite expensive, rare, and very sought after resources. Only a few countries have their own eco- nomically promising deposits of rare earths. About 63\% of rare earth ores were mined in China in 2019, about $10-12 \%$ each in the United States, Burma and Australia, and $\sim 7 \%$ in other countries. Countries that do not have domestic sources of raw materials are forced to import rare-earth products or investigate projects permitting to obtain REMs through recycling [3-5].

The demand for REMs is constantly growing by $4-7 \%$ per year, depending on the scope of use, and currently exceeds 200 thousand tons expressed as oxides. At the same time, despite the fact that a number of projects for the production of rare earths have been developed in the 
last decade, certain metals of the group are in short supply [6-7]. This situation is expected to continue in the near future.

The world REM market opportunities are largely determined by the economic policy of China, which put in practice the quotas on export of rare-earth products. Exclusively owning $\sim 90 \%$ of the world market of rare earths, the People's Republic of China not only manipulates prices, but also controls the distribution of REM commodity flows between countries. However, not only this causes an imbalance in the demand and supply of REMs, but also onrush of certain technologies that selectively consume a certain type of rare earths. For instance, rapid growth in the production of electronics, hybrid engines, and power energy installations generates an outstanding priority demand for cerium, neodymium, samarium, and yttrium.
At present, all this creates difficulties for providing consumers with rare-earth production and makes the task of finding new sources of REMs, including man-caused ones, very important [8-9].

In solving these problems, a very promising direction is the elaboration of recycling schemes for REMs, both directly from wastage of production of rare metals and other industries, and from end-of-life goods (Fig. 1).

\section{REMs of EOL goods processing}

The latter direction of recycling seems to be very appropriate based on the volumes of REMs that fall into wastage exactly in end-of-life goods. According to the analysis results for the global life cycle of lanthanum, cerium, praseodymium, neodymium, samarium, europium, gadolinium, terbium, dysprosium and yttrium, together with the final goods, about $35 \%$ of the total amount of REMs produced during the year goes to wastes. At the same time, according to experts, no more than $25 \%$ of consumer electronics, $\sim 30 \%$ of computers, $\sim 17 \%$ of television sets, $\sim 10 \%$ of mobile phones are recycled even in the United States, where REMs are considered a strategic material. Of these recycled products, up to $3 \%$ of the total amount of REMs produced on the world market is returned to useful utilization [10-12].

Recycling of used products, the socalled end-of-life (EOL) goods, has been most developed in Japan, the EU countries and China, in other words, in the countries where exist the advanced production facilities for high-value products based on REMs (Table 1). According to foreign authors, the recycling REMs from $\mathrm{NdFeB}$ magnets from electronic devices, luminescent lamps, nickelmetal-hydride $(\mathrm{NiMH})$ batteries and some other REM-containing products has become the most widespread in the processing of EOL goods [13].

The first developments in the field of REM recycling were carried out in 2009 by specialists from Hitachi company, in compliance with the governmental program for finding alternative sources of rare earths as a response to the decline in supplies from China.

\section{Processing of NdFeB - Magnets}

Hitachi has developed a technology for dismantling hard disk drives (HDD) and air conditioner compressors for further extraction of $\mathrm{NdFeB}$ magnets out of them. To separate the magnets from other parts, a mechanical method is used: 
Table 2

Main technologies for recycling REM magnets

\begin{tabular}{l|l|l|}
\hline \multicolumn{1}{|c|}{ Technology } & \multicolumn{1}{c|}{ Advantages } & \multicolumn{1}{c|}{ Disadvantages } \\
\hline Direct reuse in the existing form & The most economical and eco-friendly & $\begin{array}{l}\text { It is only applicable for large, easily remo- } \\
\text { vable magnets }\end{array}$ \\
\hline $\begin{array}{l}\text { Processing of alloys } \\
\text { after decripitation in a hydrogen } \\
\text { environment }\end{array}$ & $\begin{array}{l}\text { It is less energy-intensive than pyro- and hydro- } \\
\text { metallurgical schemes. Waste-free. Convenient } \\
\text { for HDD recycling }\end{array}$ & $\begin{array}{l}\text { Not applicable for waste recycling where } \\
\text { different types of magnets or oxidized } \\
\text { magnets are mixed }\end{array}$ \\
\hline Hydrometallurgical & $\begin{array}{l}\text { The technology is applicable for all types of mag- } \\
\text { nets, including oxidized alloys }\end{array}$ & $\begin{array}{l}\text { A multi-stage method. Lots of reagents } \\
\text { and liquid waste }\end{array}$ \\
\hline Pyrometallurgical & $\begin{array}{l}\text { The technology is applicable for all types of mag- } \\
\text { nets. Allows one to obtain a ligature from REMs } \\
\text { and extract them in the form of metals. Fewer } \\
\text { stages than in the hydrometallurgical scheme. }\end{array}$ & $\begin{array}{l}\text { Very power-consuming. Not applicable } \\
\text { for oxidized magnets. Generates a large } \\
\text { amount of solid waste }\end{array}$ \\
\hline Gas-phase extraction & $\begin{array}{l}\text { It is applicable for all types of magnets, including } \\
\text { oxidized alloys }\end{array}$ & $\begin{array}{l}\text { Toxic, uses a large amount of chlorine. } \\
\text { It is characterized by high temperatures } \\
\text { and long time }\end{array}$ \\
\hline
\end{tabular}

the HDD is placed in a rotating drum, in which the screws connecting the disk into a single whole are loosened from multiple shocks and vibrations. The disks break up in the drum, and workers can manually select the magnets that come out in a separate stream. This technology has made it possible to speed up the process of dismantling disks up to 100 pcs. per hour, without the use of toxic chemicals [14].

For compressors, Hitachi first used a body-cutting machine; then $\mathrm{NdFeB}$ magnets are manually separated from the rotor. In this case, the rotors are removed using mechanisms, and the collected magnets, in turn, are demagnetized. Applying of these developments has allowed Hitachi to get about $10 \%$ of the total corporate needs in REMs.

To date, a number of different technologies have been developed for recycling of rare earth magnets; some of them are listed in Table 2.

As can be seen from Table 2, all existing methods of recycling REM magnets have their pros and cons. Reuse of the magnets in their existing form is the most profitable approach, however, this can only be used for large and easily removable magnets in wind turbines, generators, and hybrid car engines. At the same time, the greatest quantity of REM magnets is present in a variety of electronic goods, mobile phones and hard disk drives (HDD) of computers. As specialists estimate, 600 million of HDD units produced in the world per year contain from 6 to 12 thousand tons of $\mathrm{NdFeB}$ magnets with up to $\sim 30 \%$ neodymium and up to $\sim 10 \%$ dysprosium in their composition. Taking into account the fact that the REM recovery rate during recycling of magnets by the above-mentioned methods is $80-95 \%$ according to the developers, such a volume of secondary resources of rare earths is of serious commercial interest [15-18].

Unfortunately, ample quantity of used HDDs, getting with other electronic scrap for recycling, are reduced, which causes brittle magnets to be crushed into powder. Afterwards this magnetic powder adheres to the ferromagnetic components of the scrap and it is very difficult to separate it for subsequent REM extraction. To do this, one has to use the techniques of magnetic and electrostatic separation of wastes. The scrap is then remelted in order to extract valuable components, in addition to rare earths, which are converted into metallurgical slags. And so, slags should be included in REM recycling schemes as well. For the fine magnetic fraction processing during HDD utilization, the technology of decrepetation in a hydrogen medium is more applicable, since it permits to obtain demagnetized $\mathrm{NdFeB}$ powder, and then separate it from the disk nickel coating with an efficiency of $95 \%$. This powder can then be used directly to manufacture new magnets of different types.

It should also be emphasized that a serious problem for recycling magnets from end-of-life electronics is their large variety in composition, as well as the small mass of magnets in many modern devices. As for the recycling of used electronics, one should mark the success of Mitsubishi Electric Group, which has been doing this work since 2010. Mitsubishi recycles the most commonly used household appliances: refrigerators, television sets, washing machines and air conditioners. Taking into account that the first permanent magnets with neodymium and dysprosium appeared in air conditioners in 2000, the company's specialists expect that about $65 \%$ of them will be recycled in 2020. However, employees of the University of Tokyo cite ambiguous data on the processing of air conditioners. Thus the costs of REM recycling from the engine of one air conditioner is about 1.5 thousand yen, and the value of rare earths, as well as copper and steel obtained as a result of utilization, is only about 1 thousand yen. Such a proportion of costs and benefits, in turn, aims specialists at developing the schemes for neodymium and dysprosium recycling from air conditioner motors that are more efficient from an economic point of view (Fig. 2 [19]).

According to the strategy of the U. S. Department of Energy, the problems of HDD utilization with the extraction of rare earths are solved within the framework of the 

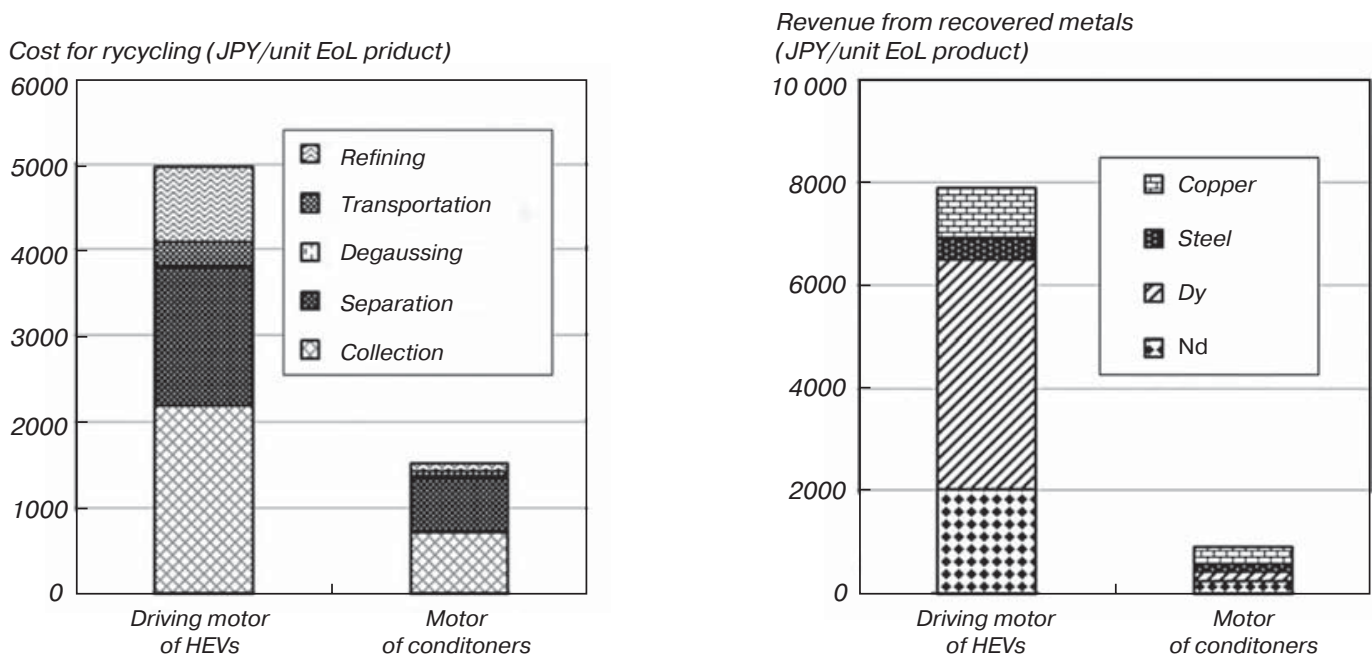

Fig. 2. Expenses and revenues from recycling REM from spent hybrid car engines and air conditioners

iNEMI project in its own way. Specialists of the Oakridge National Atomic Energy Laboratory have simplified the method of extracting magnets by using the location of the latter in hard disks. Cutting off the left corner of the storage device, the elements are heated up to $380{ }^{\circ} \mathrm{C}$ for loss of magnetic properties and then the magnets are separated. The recovered secondary raw materials are ground to a micron-sized powder, and then the magnetic fraction is extracted from the total mixture and new magnets are formed from it. One processing line such as that can process more than 7 thousand tons of HDD per day [20].

A possible future leader in the field of REM recycling, the Canadian company Geomega Resources, forecasts the market volume growth for the processing of rare earth magnets up to 1.8 billion dollars by 2030 . According to the company information, 160 thousand tons of $\mathrm{NdFeB}$ magnets used in electric and hybrid engines and wind turbines are produced annually in the world. For example, on average, one electric motor contains up to $3 \mathrm{~kg}$ of $\mathrm{NdFeB}$ magnets, and a three-megawatt turbine contains up to 2 tons. Almost $15-30 \%$ of magnets go to waste products, which permits to get up to 21 thousand tons of $\mathrm{NdFeB}$ magnets per year. Specialists from Geomega Resources managed to develop an effective low-cost ISR technology for recycling NdFeB magnets: at capital costs of 2.6 million dollars per factory and direct operating expences of 3 dollars per kg of REM oxides, the ISR process allows to obtain per day up to $4.5 \mathrm{t}$ of the magnet recycling product containing up to $30 \%$ of neodymium, praseodymium, dysprosium, and terbium [21].

\section{Processing of fluorescent lamps}

Another important area of recycling rare earths from EOL goods is the utilization of fluorescent lamps. According to estimations of Belgian analysts, waste lamps contain more than 20,000 tons of rare earths. At the same time, REM recovery from lamps is somewhat easier than from magnets. The main methods of REM recycling from fluorescent lamps are given in Table 3 [15, 22].

Five types of phosphors are most commonly used in luminescent lamps: red (YOX) based on yttrium and europium; three green phosphors (LAP, CBT, CAT) containing lanthanum, cerium, gadolinium, terbium, as well as blue (BAM) based on europium. In addition, the recycled lamps contain a significant amount of aluminum and silicon oxides, which form in the lamps a barrier layer between the glass bulb and the mercury vapors that fill it. Modern fluorescent lamps contain $2.5-3.5 \mathrm{mg}$ of $\mathrm{Hg}$. It is the content of mercury in the lamps that makes them dangerous waste that requires special protective measures during disposal. To meet ecostandards in the course of

Table 3

Main technologies for REM recycling from fluorescent lamps

\begin{tabular}{|c|c|c|}
\hline Technology & Advantages & Disadvantages \\
\hline Direct reuse & $\begin{array}{l}\text { The easiest way. Chemical processes are not } \\
\text { used }\end{array}$ & $\begin{array}{l}\text { It is applicable only for individual lamps in } \\
\text { which different phosphors can be used. } \\
\text { Phosphors are destroyed during the service } \\
\text { life of the lamp }\end{array}$ \\
\hline $\begin{array}{l}\text { Separation of phosphors into individual } \\
\text { components }\end{array}$ & $\begin{array}{l}\text { It is relatively simple. It does not require a } \\
\text { large amount of chemicals }\end{array}$ & $\begin{array}{l}\text { It is difficult to obtain a pure phosphor } \\
\text { fraction. Phosphor particles may change } \\
\text { during the separation process. Phosphors } \\
\text { are destroyed during the service life of the } \\
\text { lamps }\end{array}$ \\
\hline Recovery of REM components & $\begin{array}{l}\text { It is applicable for all types of phosphors. } \\
\text { Gives very pure REM oxides }\end{array}$ & $\begin{array}{l}\text { A multi-step process. Many chemicals are } \\
\text { used. Produces a lot of liquid wastes }\end{array}$ \\
\hline
\end{tabular}


recycling process, mercury is transferred into an insoluble form, in particular, by heating the phosphors [22]. At the end of their service life, the lamps are gathered by specialized companies that recycle their glass and metal parts.

Lamps of linear-tubular shape are most easily recycled: the ends of the tubes are cut off and the phosphor is blown out of the bulbs. However, lamps of other shapes are not so easy to recycle. As in the case of other waste products, they are crushed and then sifted. However, it is not possible to completely remove transparent glasses from the phosphor powder; that reduces the value of the recycled phosphors, which make up only $3 \%$ of the mass of a fluorescent lamp. Therefore, and taking into account the fact that phosphors have a complex chemical composition, in most countries REMs are not extracted from them. After processing in order to convert mercury into an insoluble form, phosphors are buried or placed in special containers.

Commercial projects for the recovery of rare earths from spent fluorescent lamps are currently being implemented by Solvay and OSRAM companies. In 2011 Solvay acquired Rhodia company, researchers of which have developed a technology for recovering REMs from flurescent lamps. Solvay produces from phosphor a rareearth concentrate containing $\mathrm{La}, \mathrm{Ce}, \mathrm{Eu}, \mathrm{Gd}, \mathrm{Tb}$, and $\mathrm{Y}$, which is then separated into individual REM oxides. At a subsequent stage, they are used to make new phosphors (mainly red and green) for fluorescent lamps. At that, the chemical company Solvay has plans to extract $90 \%$ of REMs contained in fluorescent lamps. This means the return to commercial circulation of $\sim 188$ tons of rare earths when processing 3.3 thousand tons of waste. Specialists in OSRAM have developed a process for the recovery of REMs from the phosphors decomposed by selective leaching, followed by deposition of rare earth oxalates and manufacturing of REM oxides from them [23].

Modeling the progress in the situation with the collection of fluorescent lamps and recycling REM from them, an international group of researchers have obtained an optimistic scenario that the share of EOL-lighting devices involved in the recycling will exceed $50 \%$ resulting from collection of $70 \%$ of lamps, and the level of recycling rare earths from them will be $\sim 95 \%$. Despite the positive forecasts, it should be emphasized that due to the development of technologies, fluorescent lamps are gradually being replaced by LED ones containing hundreds of times less REM (Fig. 3).

Nevertheless, it is estimated that it will be possible to recycle fluorescent lamps for the purpose of extracting REM for another 30 years [24-25].

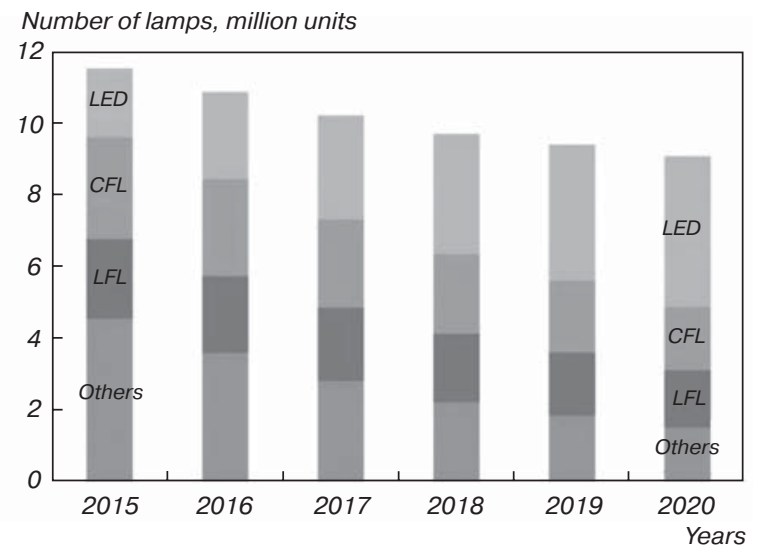

Fig. 3. Dynamics of the structure of the world market of lighting devices by types of lamps used:

LED - light-emitting diode lamps; LFL - linear fluorescent lamps; CFL - compact fluorescent lamps

\section{Processing of NiMH - batteries}

The third line of recycling of EOL goods for extracting rare earths is the processing of nickel-metal hydride (NiMH) batteries. The main ways of REM recycling from them are given in Table 4.

The use of rare earths in batteries is based on their ability to retain hydrogen. For example, $\mathrm{LaNi}_{5}$ so energetically absorbs hydrogen that the density of the latter in $\mathrm{LaNi}_{5} \mathrm{H}_{6}$ is higher than in liquid hydrogen by almost $\sim 24 \%$. $\mathrm{LaNi}_{5}$ alloys are effective anodes, but are quite expensive because of the presence of pure lanthanum. Therefore, for wide commercial use, La began to be replaced with misch metal an undivided mixture of light REMs: La, Ce, Pr, Nd. Despite the fact that the ability of misch metals to retain hydrogen is lower than that of a lanthanum-nickel alloy, misch metals are more resistant to an alkaline environment and crumble less.

Spent NiMH batteries contain $36-42 \% \mathrm{Ni}, 3-4 \%$ Co, $8-10 \%$ of misch metal - and this is about $2.5 \mathrm{~kg}$ of REMs for hybrid car batteries. However, rare earths have been uselessly lost in the disposal of such batteries, since the latter were processed exclusively as a cheap source of nickel. Over the past few years, the processes of hydrometallurgical processing of NiMH batteries with extraction of cobalt, nickel and rare earths have been developed, and the degree of REM recovery from chloride solutions amounts to $97.8 \%$ [26].

In 2011, Umicore and Rhodia announced that they had jointly developed a process for recycling rare earth elements from NiMH batteries based on ultra-high tem-

Table 4

Main technologies for REM recycling from NiMH batteries

\begin{tabular}{|c|c|c|}
\hline Technology & Advantages & Disadvantages \\
\hline Hydrometallurgical & Low costs. Recycling is possible from various types of waste & $\begin{array}{l}\text { Many manual operations. Large amount of } \\
\text { chemicals }\end{array}$ \\
\hline Pyrometallurgical & $\begin{array}{l}\text { Technology is well-developed. Individual slag processing oper- } \\
\text { ations are similar to primary ore ones. The possibility of obtain- } \\
\text { ing additional energy from the disposal of organic components }\end{array}$ & $\begin{array}{l}\text { High costs. The need for subsequent extrac- } \\
\text { tion of REM from slags. The necessity to sep- } \\
\text { arate REM after obtaining a group alloy }\end{array}$ \\
\hline
\end{tabular}


perature smelting. A pilot factory exploiting this technology to produce rare earths was built in Hoboken (Belgium). Its capacity allows to process 250 million mobile phones and 150 thousand engines from hybrid vehicles per year.

Japanese companies Honda and Japan Metals Chemicals (JMC) are also engaged in the processing of NiMH batteries for extraction of rare earths using electrolysis in molten salts. The extracted metals are supplied to the battery manufacturers for producing the corresponding components. Thus, up to $80 \%$ of REMs contained in $\mathrm{NiMH}$ batteries is returned to commercial circulation.

Korean engineers have proposed an effective method for recycling REMsfrom spent NiMH batteries(Fig.4). Despite the fact that the overwhelming majority of European, American and Asian companies use pyrometallurgical technologies for processing hybrid batteries, Korean developers have managed to implement the technology for extracting La, Ce and Nd by hydrometallurgy, using simple wet chemical valorization process. The process stages include the discharge and grinding of spent batteries, acid

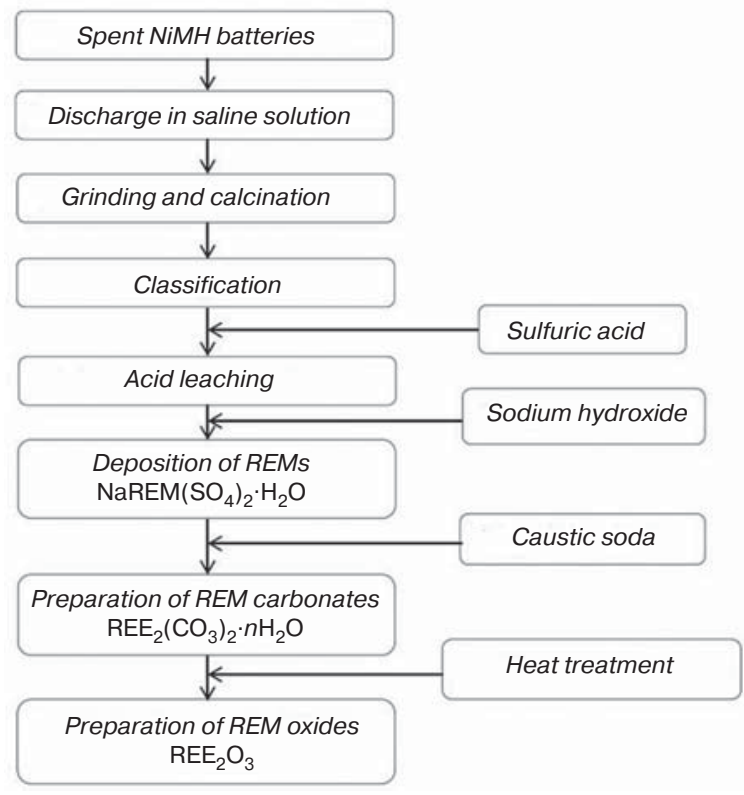

Fig. 4. Diagram of the hydrometallurgical process for extracting REMs from spent NiMH batteries leaching followed by selective deposition of REM salts and the release of rare earth oxides. The precipitate released contains $17.2 \% \mathrm{Ce}, 13.1 \% \mathrm{La}$, and $5.4 \% \mathrm{Nd}$ by mass. This process, according to the authors, is quite simple, universal, and less toxic. It can be implemented as a large-scale production [27-29].

\section{Inference}

As can be seen from the above-described schemes for extracting REMs from nonproduction waste products, the implementation of recycling has a number of difficulties despite the dynamic development of technologies. The first problem is the need to ensure the purity of materials sent for recycling in order to exclude impurities that impede extraction of rare metals. The second problem is the toxicity of the applied chemical and metallurgical schemes for the disposal of consumer and industrial REM-containing wastes, as well as minimizing the damage from them to the environment. The third problem consists in the large-scale dispersion of REMs in goods and other products due to their low content per consumer unit, which significantly complicates their extraction.

Concluding the consideration of REM recycling from end-of-life goods, we can give a forecast of expansion of this field of activity, made by Dutch researchers [30]. The forecasting figures reflect the change in the coverage share of future demand for $\mathrm{Nd}$ and Dy due to their recycling from magnets for the next 10 years. The value of future demand is determined by the amount of neodymium and dysprosium in the end-of-life goods. Thus, the potential share of demand coverage was determined by formula (1):

$$
\begin{aligned}
& \text { Share of demand } \\
& \text { coverage by recycling }
\end{aligned}=\frac{\text { REMs in utilized EOL goods }}{\text { REMs in all EOL goods }}
$$

The calculation was made from an estimation of $\mathrm{Nd}$ and Dy amounts in magnets installed in HDD, wind turbines, and hybrid engines. As can be seen from the results of the calculations given in Table 5, the first percentages of ensuring the demand for these REMs owing

Table 5

Forecast of the share of demand coverage for $\mathrm{Nd}$ and Dy due to their recycling from wind turbine magnets, hybrid vehicles and computer hard disk drives

\begin{tabular}{|c|c|c|c|c|c|c|}
\hline \multirow{2}{*}{$\begin{array}{l}\text { Sources } \\
\text { of recycling }\end{array}$} & \multicolumn{2}{|c|}{2020} & \multicolumn{2}{|c|}{2025} & \multicolumn{2}{|c|}{2030} \\
\hline & $\begin{array}{c}\text { Volume } \\
\text { of recycling, } t\end{array}$ & $\begin{array}{c}\text { Share } \\
\text { of coverage, \% }\end{array}$ & $\begin{array}{c}\text { Volume } \\
\text { of recycling, } t\end{array}$ & $\begin{array}{c}\text { Share } \\
\text { of coverage, \% }\end{array}$ & $\begin{array}{c}\text { Volume } \\
\text { of recycling, } t\end{array}$ & $\begin{array}{c}\text { Share } \\
\text { of coverage, \% }\end{array}$ \\
\hline Wind turbines (Dy) & 0 & 0 & 20 & 1 & 210 & 10 \\
\hline Hybrid vehicles (Nd) & 40 & 1 & 230 & 3 & 830 & 6 \\
\hline Hard disk drives (Nd) & 410 & 54 & 380 & 40 & 380 & 36 \\
\hline Total (Nd) & 450 & 5 & 690 & 4 & 2210 & 9 \\
\hline Total (Dy) & 10 & 0 & 90 & 2 & 460 & 7 \\
\hline
\end{tabular}


to the recycling magnets from hybrid engines appear only now, and that from turbines will appear only in 5 years. At the same time, the dominant component of $\mathrm{Nd}$ and Dy recycling falls at HDD.

According to the forecast, even in 10 years, neither for the more common neodymium, nor for the more expensive dysprosium, their recycled volume from secondary raw materials will not exceed $10 \%$ of the total volume of these metals in end-of-life goods. However, an increase in the share of demand coverage, and, consequently, growth in the volume of recycling REMs from the used goods, is predicted with confidence.

\section{Recycling REMs of industrial waste}

Another area of REM recycling of exceptional importance is the disposal of industrial wastes that contain rare metals. Such technologies can be developed in the countries where there is no production of REM products with high value added, however, there are mineral resources and advanced industry. In particular, recycling rare earths from production wastes is the most promising in Russia. Currently, the Russian producer of rare earths actively exploits the Lovozero deposit of loparite, which is then processed at the Solikamsk Magnesium Works JSC - the only domestic enterprise

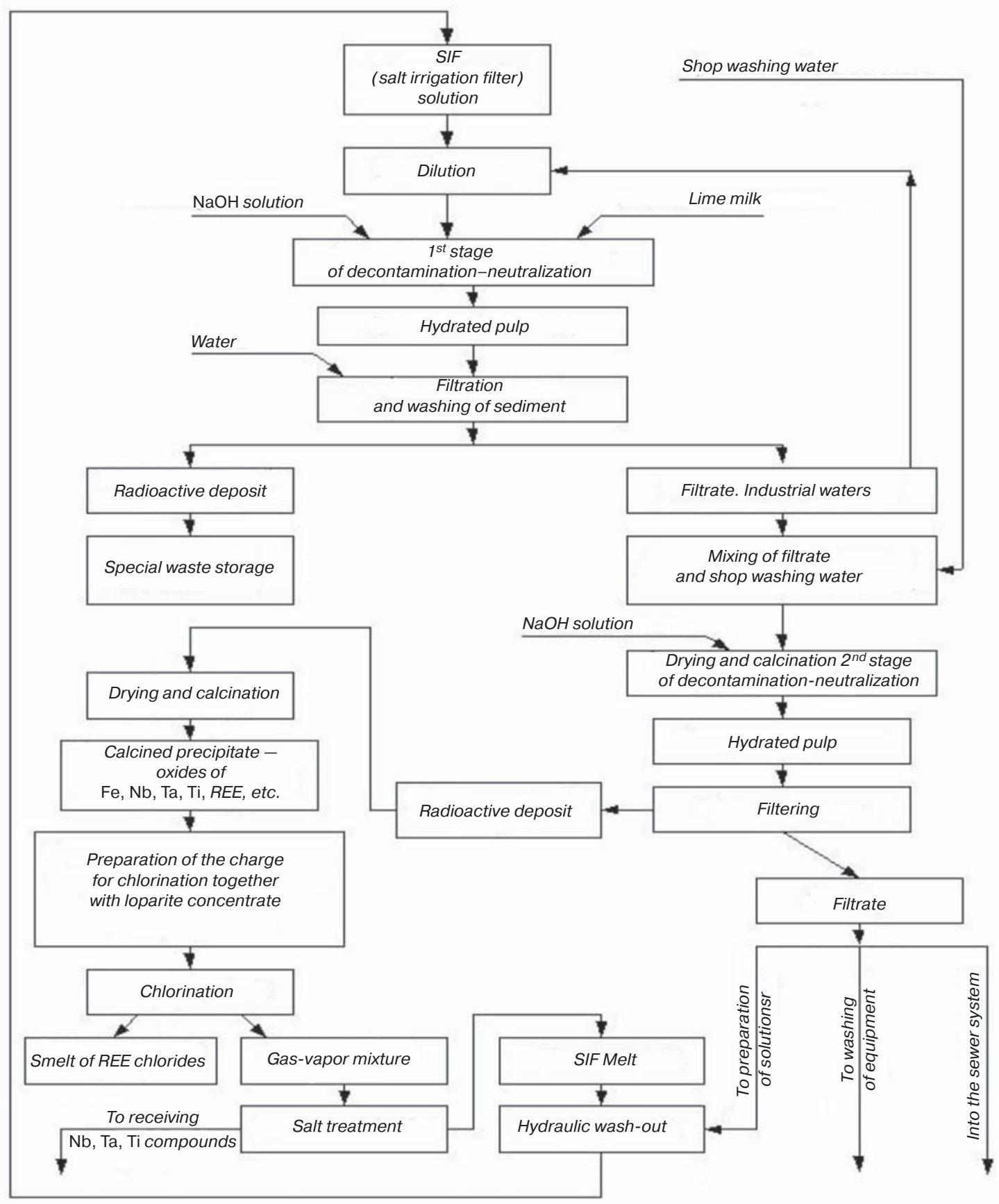

Fig. 5. Technology of disposal of rare-metal production wastes of the Solikamsk magnesium works 
that manufactures large-capacity rare-metal production [31]. The chlorine technology used at the enterprise for loosening loparite concentrate is characterized by the formation of a significant amount of liquid and solid production wastes. Analysis of this system has allowed developing a technology for recycling precipitates from liquid wastes (Fig. 5).

This technical solution makes it possible to return to the production cycle about $\sim 300$ tons per year of neutralized wastes for preparing the main raw materials.

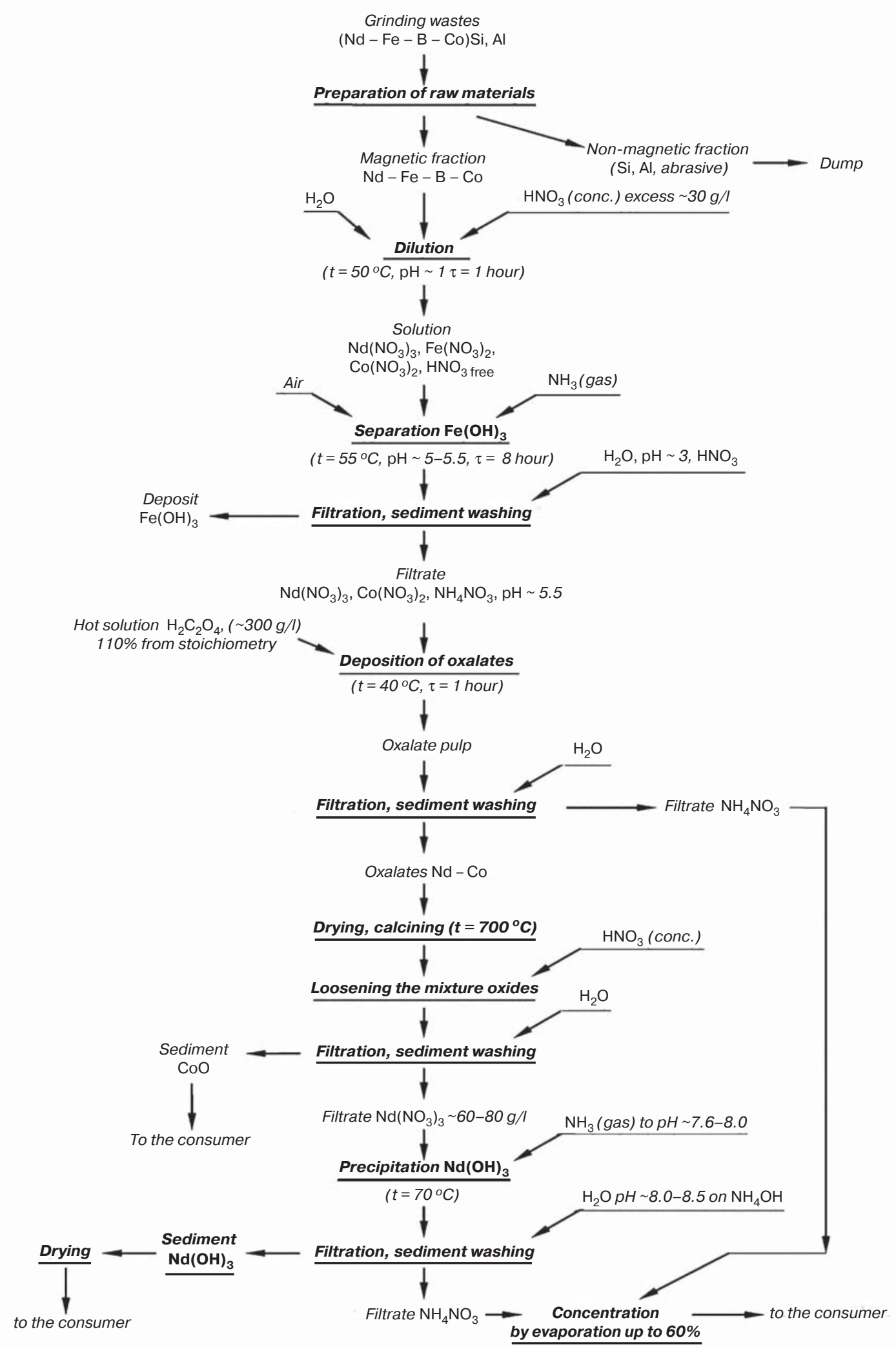

Fig. 6. Technology of grinding waste processing 
Considering that the sediment sent for recovery contains $\sim 17.79 \%$ wt. of REMs, the recycling prevents losses of $\sim 55 \mathrm{t} /$ year of rare earths.

It can also be noted that the special storage facility, where the works has been storing wastes for four decades, is a promising technogenic deposit of rare metals. Over the $t$ years, it has accumulated about $\sim 13$ thousand tons of REMs [32].

Another Russian plant, Russian Rare Metals, has developed a technology for processing grinding wastes from the production of high-energy permanent magnets based on $\mathrm{Nd}_{6} \mathrm{Fe}_{14} \mathrm{~B}$ type rare earth metals. According to the existing technology for preparing magnets, about $10-40 \%$ of magnetic material is lost with grinding wastes containing $\sim 30 \%$ wt. of $\mathrm{Nd}$ plus $\mathrm{Tb}, \mathrm{Dy}, \mathrm{Er}$, $\mathrm{Yb}$ alloying additives, which make up 1-3\% wt. The scheme includes the following basic operations: preparation of raw materials, dissolution of raw materials in nitric acid, separation of iron in the form of hydroxide, co-precipitation of neodymium-cobalt oxalates, separation of cobalt as oxide and deposition of neodymium as $\mathrm{Nd}(\mathrm{OH})_{3}$ (Fig. 6).

The resulting dried sediment contains $\sim 74.6 \%$ wt. of oxides of REMs. As the developers note, the elaborated recycling technology has the following points [33]:

1. As raw materials, there are used the wastes from manufacturing of high-energy permanent magnets, the disposal of which requires inputs.

2. In the process of isolation of rare earth hydroxides, they are completely separated from the main accompanying impurities - iron and cobalt.

3. The commercial product, according to the analysis data, is suitable for subsequent processing by extraction separation of rare elements with obtaining high-purity compounds of neodymium, praseodymium, and dysprosium.

Assessing the opportunities and prospects for the development of REM recycling in Russia from production waste products, it is necessary to mention the colossal technogenic resource for this purpose - phosphogypsum wastes of the Khibiny apatite concentrate processing. Just taking into account the rare earths extracted from phosphogypsum it is possible to predict the large-scale development of their recycling in our country for $2-3$ decades to come [34].

Khibiny apatite is the world's best raw materials for the production of phosphorus fertilizers. It is for this commercial purpose that it is currently extracted, without extracting other valuable components. It contains $0.4-1.0 \%$ wt. of REMs, which passed into phosphogypsum wastes from apatite mining. However, it is the mineral resources of Khibiny apatite that make up almost $40 \%$ of the domestic balance reserves of yttrium and REMs. Until the mid1980s they have been extracted in course of processing of apatite concentrates at enterprises of the USSR Ministry of Medium-Scale Mechanical Engineering, later in the 1990s their extraction was stopped. Today, Russian chemical holding PhosAgro manufactures 8-9 million tons of apatite concentrates per year. It is processed into fertilizers by two methods (Fig. 7).

About $15 \%$ of apatite is worked by the nitric-acid method, and the remaining $85 \%$ - by sulfuric-acid one, through which $\sim 50-60 \%$ of rare earths pass into phosphogypsum.

Over the long years of operation of the enterprises, more than $\sim 250$ million tons of stale phosphogypsum have been accumulated in the dumps, which are annually replenished with $\sim 11$ million more of fresh one [36]. Considering new analytical data on the content of REMs in the mineral fractions of the formed technogenic deposits, they can contain millions of tons of rare metals [35]. This allows regarding the phosphogypsum wastes from processing of Khibiny apatite the most promising raw material source of rare metals in the Russian Federation. One of the first solutions for recycling REMs from phosphogypsum was carried out by the Skygrad Group of companies. Phosphogypsum of Voskresensk and Volkhov chemical combines has been used for testing. With moderate initial investments of $\sim 120$ million rubles, the company's specialists have developed a three-cascade extraction technology with 200 stages, which allows to extract up to $3.5 \mathrm{~kg}$

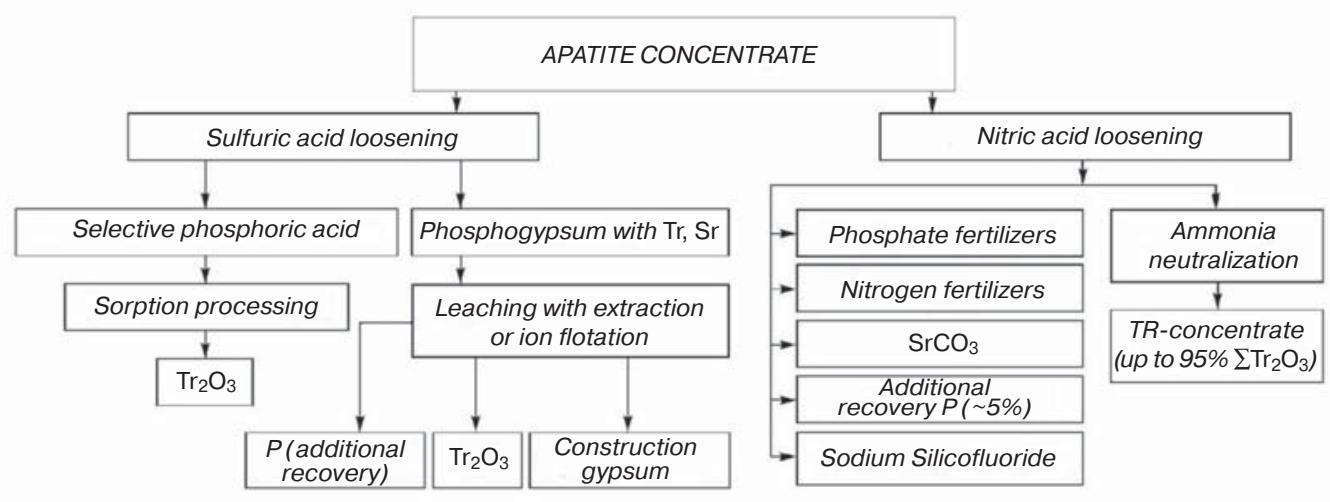

Fig. 7. The apatite concentrate processing methods to produce REMs 


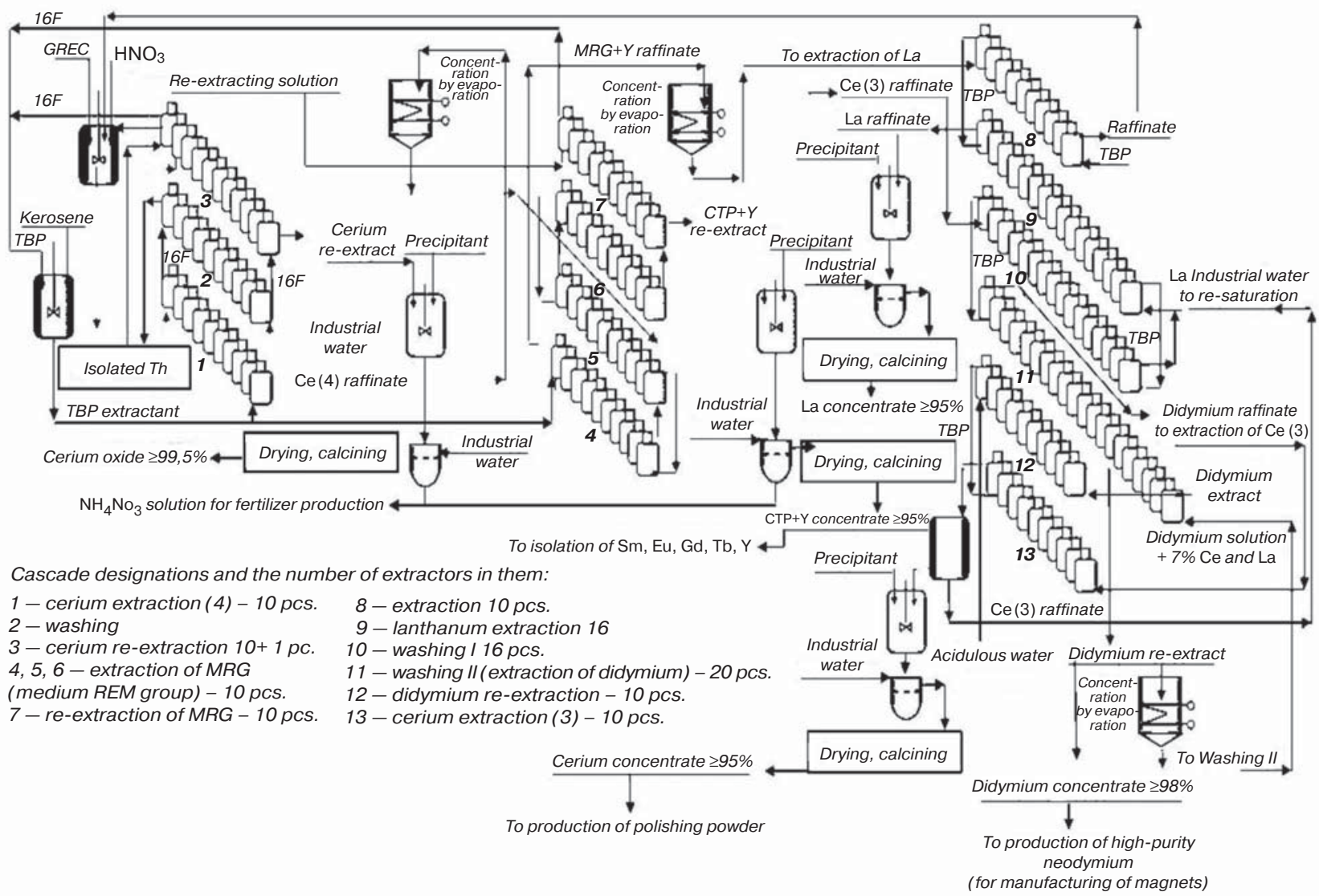

Fig. 8. Hardware scheme for processing GREC extracted from phosphogypsum, developed in LIT LLC, Skaygrad Group of Companies (up to $1000 \mathrm{t}$ of GREC per year)

Table 6

REM distribution by elements, \%

\begin{tabular}{l|c|c|c|c|c|c|c|c|c|c|c|c|c|}
\hline \multirow{2}{*}{ Type of concentrate } & \multicolumn{10}{|c|}{ Rare-earth element } \\
\cline { 2 - 29 } & $\mathrm{La}_{2} \mathrm{O}_{3}$ & $\mathrm{CeO}_{2}$ & $\mathrm{Pr}_{6} \mathrm{O}_{11}$ & $\mathrm{Nd}_{2} \mathrm{O}_{3}$ & $\mathrm{Sm}_{2} \mathrm{O}_{3}$ & $\mathrm{Eu}_{2} \mathrm{O}_{3}$ & $\mathrm{Gd}_{2} \mathrm{O}_{3}$ & $\mathrm{~Tb}_{4} \mathrm{O}_{7}$ & $\mathrm{Dy}_{2} \mathrm{O}_{3}$ & $\mathrm{Ho}_{2} \mathrm{O}_{3}$ & $\mathrm{~Eb}_{2} \mathrm{O}_{3}$ & $\mathrm{Y}_{2} \mathrm{O}_{3}$ & $\mathrm{Yb}_{2} \mathrm{O}_{3}$ \\
\hline $\begin{array}{l}\text { Group rare-earth } \\
\text { concentrate }\end{array}$ & 20.49 & 45.9 & 5.06 & 17.00 & 2.34 & 0.62 & 1.77 & 0.07 & 0.94 & 0.14 & 0.27 & 3.50 & 0.10 \\
\hline Loparite concentrate & 20.66 & 56.5 & 5.25 & 14.1 & 0.87 & 0.18 & 0.15 & 0.02 & 0.11 & 0.02 & 0.00 & 0.023 & 0.00
\end{tabular}

of REM oxides from 1 ton of phosphogypsum, and to obtain from 500 to 2000 tons of the group rare-earth concentrate (GREC) per year. Such a concentrate contains 17 rare earth metals, with their total mass fraction up to $99.5 \%$, while the level of their extraction into marketable products during further processing of the concentrate reaches $78.3 \%$. The resulting concentrate prime cost is at the level of 13-14 US dollars per $1 \mathrm{~kg}$. The existing multi-stage scheme makes it possible to separate and obtain all rare earths, including $\mathrm{Y}$ and Sc (Fig. 8). At the following stages of work, the Skaygrad Group plans to invest funds into production of $\mathrm{Sm}-\mathrm{Co}$ magnets [37-38].

Given the common problem of low REM content in all types of recycled wastes, it is expedient to compare phosphogypsum with the known mineral rare-earth raw materials. Comparing the group concentrate from phosphogypsum with loparite one by the content of REMs, it can be noted that phosphogypsum may be of commercial interest as technogenic raw materials for obtaining rare earths (Table 6). According to current data, the price basket of REMs of the group concentrate from phosphogypsum is $94 \%$ of the level of that of loparite concentrate [39].

\section{Conclusion}

In conclusion, it can be mentioned that within the next few years, China's dominance in the global market of REMs is likely to continue, and the raw dependence and technological vulnerability of countries developing advanced technologies in power engineering, electronics, optics, etc. will remain as well. The search for sources of rare-earth raw materials will certainly be implemented, including the field of REM recycling, both from endof-life goods and products, and from industrial wastes, despite the dispersion and relatively low content of rare earths in them. At the same time, it seems that the development of technologies for recycling of the used electronic devices and energy installations, as well as technologies 
for processing of mining waste products, will be accented in the near future. The implementation of such technological projects will be carried out not only in the countries of the Asia-Pacific region or EU, but also in Russia.

\section{References}

1. Rare Earth Elements: A Review of Production, Processing, Recycling, and Associated Environmental Issues. EPA/600/ R-12/572, December 2012 Revised. Cincinnati: NRMRL, 2012. $135 \mathrm{p}$.

2. Kondratyev V. B. Peru as a New Actor in Global Mining Equipment Value Chain. Russian Mining Industry. 2017. No. 4. pp. $48-54$.

3. Izyumov D. B., Kondratyuk E. L. Production of Rare Earth Metals in The Interests of Defense and the Impact of Regulatory Restrictions on The Industry in the United States. Innovatics and Expert Examination. 2019. No. 3. pp. 175-182.

4. U.S. Geological Survey, 2020, Mineral Commodity Summaries 2020: U.S. Geological Survey, 200 p. DOI: 10.3133/mcs2020.

5. Yushina T. I., Petrov I. M., Grishaev S. I., Chernyi S. A. International Rare Earth Metals Market and Processing Technologies: State-of-the-Art and Future Prospects. Gornyi Zhurnal. 2015. No. 2. pp. 59-64. DOI: 10.17580/gzh.2015.02.11

6. Alonso E., Sherman A. M., Wallington T. J., Everson M. P., Field F. R., Roth R., Kirchain R. E. Evaluating Rare Earth Element Availability: A Case with Revolutionary Demand from Clean Technologies. Environmental Science Technology. 2012. Vol. 46, Iss. 6. pp. 3406-3414

7. Chernyi S. A. Comparative Valuation of Rare Earth Metal Deposits. Mineralnye Resursy Rossii. Ekonomika i Upravlenie. 2013. № 3. pp. 37-41.

8. Doriomedov M. S., Sevastyanov D. V., Shein E. A. Technological, Institutional and Economic Trends in The Industry of Rare and Rare-Earth Metals (Review). Proceedings of VIAM. 2019. No. 7. pp. 3-11.

9. Petrov I. M. Russia Imports up to $90 \%$ of Rare Earth Metals. The Rare Earth Magazine. August, 3, 2016. URL: http://rareearth. ru/ru/pub/20160803/02352.html (accessed: 21.04.2021).

10. Du X. Y., Graedel T. E. Uncovering the Global Life Cycles of the Rare Earth Elements. Scientific Reports. 2011. Vol. 1, Iss. 1. 145. DOI: 10.1038/srep00145.

11. Peterson E. S., Jones E. Improving Rare Earth Reuse and Recycling. Presentation of $248^{\text {th }}$ American Chemical Society Meeting San Francisco, 10-14 August, 2014. URL: http://www. aiche.org/sites/default/files/docs/conferences/event/d.2_peterson_suschem_final.pdf (accessed: 21.04.2021).

12. Binnemans K., Jones P. T. Rare Earths and the Balance Problem. Journal of Sustainable Metallurgy. 2015. Vol. 1, Iss. 1. pp. 29-38.

13. Bongaerts J. C., Liu J. Production Process and Recycling of Rare Earth Elements. The IMRE Journal. 2013. Vol. 7, Iss. 2. pp. 1-9. URL: https://tu-freiberg.de/sites/default/files/media/ imre-2221/IMREJOURNAL/2013_10_01_imre_journal_ new_rare_earth.pdf (accessed: 21.04.2021).

14. Hitachi Develops Recycling Technologies for Rare Earth Metals. Hitachi Ltd., December 6, 2010. URL: http://www.hitachi.com/New/cnews/101206.html
15. Binnemans K., Jones P. T., Blanpain B., van Gerven T., Yang Y., Walton A., Buchert M. Recycling of Rare Earths: a Critical Review. Journal of Cleaner Production. 2013. Vol. 51. pp. 1-22.

16. Vinay Kumar, Manis Kumar Jha, Archana Kumari, Rekha Panda, J. Rajesh Kumar, Jin Young Lee. Recovery of Rare Earth Metals (REMs) of Primary and Secondary Resources. In: Rare Metal Technology. N.J.: Walley, 2014. pp. 81-88.

17. Takeda O., Okabe T. H. Current Status on Resource and Recycling Technology for Rare Earths. Metallurgical and Materials Transactions E. 2014. Vol. 1, Iss. 2. pp. 160-173.

18. Dupont D., Binnemans K. Recycling of Rare Earths from NdFeB Magnets Using a Combined Leaching/Extraction System Based on the Acidity and Thermomorphism of the Ionic Liquid [Hbet][Tf ${ }_{2}$ N]. Green Chemistry. 2015. Vol. 17, Iss. 4. pp. 2150-2163.

19. Sekine N., Daigo I., Matsuno Y., Goto Y. Dynamic Substance Flow Analysis of Neodymium and Dysprosium Associated with Neodymium Magnets in Japan. The $6^{\text {th }}$ International Conference on Life Cycle Management in Gothenburg, 2013. URL: http://conferences.chalmers.se/index.php/LCM/LCM2013/ paper/viewFile/641/239 (accessed: 21.04.2021).

20. Value Recovery from Used Electronics Project, Phase 2 (August 2019). URL: http://thor.inemi.org/webdownload/2019/ iNEMI-Value_Recovery2_Report.pdf (accessed: 21.04.2021).

21. Rare Earth Element (REE) Recycling for the Permanent Magnet Industry. Corporate presentation, January 2020. URL: https://ressourcesgeomega.ca/wp-content/uploads/2020/01/ 2020-01-GMA-Presentation-ENG.pdf (accessed: 21.04.2021).

22. Tunsu C., Retegan T., Ekberg C. Sustainable Processes Development for Recycling of Fluorescent Phosphorous Powders - Rare Earths And Mercury Separation: a Literature Report. Chalmers University of Technology, Gothenburg, Sweden, 2011.65 p.

23. Binnemans K., Jones P. T. Perspectives for the Recovery of Rare Earths from End-of-Life Fluorescent Lamps. Journal of Rare Earths. 2014. Vol. 32, Iss. 3. pp. 195-200.

24. Machacek E., Richter J. L., Habib K., Klossek P. Recycling of Rare Earths From Fluorescent Lamps: Value Analysis Of Closing-The-Loop Under Demand And Supply Uncertainties. Resources, Conservation and Recycling. 2015. Vol. 104. pp. 76-93.

25. Sevastyanov D.V., Doriomedov M. S., Sutubalov I. V., Kulagina G. S. Directions for the Development of Manufacturing Technologies in The Field Of Rare Earth Metals. Proceedings of VIAM. 2018. No. 1. pp. 31-40.

26. Linyan $\mathrm{Li}$, Shengming $\mathrm{Xu}$, Zhongjun Ju, Fang Wu. Recovery of $\mathrm{Ni}, \mathrm{Co}$ and Rare Earths from Spent Ni-metal Hydride Batteries and Preparation of Spherical $\mathrm{Ni}(\mathrm{OH})_{2}$. Hydrometallurgy. 2009. Vol. 100, Iss. 1-2. pp. 41-46.

27. Presentation of Hoboken plant, Umicore, 2012. URL: https://www.umicore.com/storage/migrate/2012SeptHoboken SiteVisitEN.pdf (accessed: 21.04.2021).

28. Ivaschenko A. The World's First Recycling System for Old Batteries from Honda. FacePla.net, March, 6, 2013. URL: http://www.facepla.net/the-news/eco-transportation-mnu/ 3370-honda-recycling-used-ev-batteries.html

29. Nak-Kyoon Ahn, Basudev Swain, Hyun-Woo Shim, Dae-Weon Kim. Recovery of Rare Earth Oxide from Waste 
NiMH Batteries by Simple Wet Chemical Valorization Process. Metals. 2019. Vol. 9, Iss. 11. 1151. DOI: 10.3390/met9111151.

30. Rademaker J. H., Kleijn R., Yang Y. Recycling as a Strategy against Rare Earth Element Criticality: A Systemic Evaluation of the Potential Yield of NdFeB Magnet Recycling. Environental Science \& Technology. 2013. Vol. 47, Iss. 18. pp. 1012910136.

31. Review of the Rare Earth Elements (Metals) Market in the CIS and the World ( $11^{\text {th }}$ ed.). Moscow : INFOMINE Research Group, 2018. 196 p.

32. Kudryavsky Yu. P., Zhulanov N. K., Melnikov D. L. et al. Process Division for Decontamination of Salt Wastes from the Chlorination Process of REE Titanium-Niobates. RF Patent for a Utility Model No. 62112 under Application No. 2005140815/22 (044572) with Priority of 17.11. 2006, Registered and Published on 27.03.2007. Bulletin No. 09.

33. Glushchenko Yu. G., Larichkin F. D., Sibilev A. S. Extraction of Neodymium Oxide from Grinding Waste from Permanent Magnet Production: Issues of Technology and Economic Efficiency (Materials of The Rusredmet Group of Companies Website). URL: https://rusredmet.ru/f/vydelenie-neodima-posle-rezenzirovaniya---kopiya.pdf (accessed: 21.04.2021).

34. Samonov A. E. Commodity Priorities Speedy Recovery and Sistainable Development of the Rare Earth Industry in Russia. Tsvetnye Metally. 2012. No. 3. pp. 16-21.
35. Bykhovsky L. Z. Existing, Potential and Promising Sources of Rare Earth Minerals in Russia. Mineralnye Resursy Rossii. Ekonomika i Upravlenie. 2014. No. 4. pp. 2-8.

36. Samonov A. E. Study of Mineral Forms of Rare Metals in Industrial Waste Processing Fosfogipsovyh Khibin Apatite. Prospect and Protection of Mineral Resources. 2011. No. 4. pp. $78-80$.

37. Abramov A. M., Galiev R. S., Sobol Yu. B. Organization of REM Production in the Complex Processing of Phosphogypsum: Topical Issues. Relevant Issues of Extraction, Production and Application of Rare Earth Elements in Russia : Collection of Reports of the All-Russian Conference. Seversk: Izdatelstvo STI NIYaU MIFI, 2013. pp. 55-59.

38. Abramov A.M., Volobuev O. I., Galieva Zh. N. et al. Organization of Pilot Manufacturing for Separation of Group Rare-Earth Concentrates (GREC) with Production of Individual Compounds of Lanthanum, Cerium, Neodymium, Praseodymium and the Medium REE Group Concentrate. Relevant Issues of Obtaining and Applying REM and RM-2017: Collection of Materials of the Scientific and Practical Conference. June 21-22, 2017. Moscow : OAO "Institut "GINTSVETMET", 2017. pp. $148-151$.

39. Data on the prices of REM of the SMM Consulting portal. URL: https://price.metal.com/Rare-Earth-Metals (accessed: 21.04.2021). 